\title{
SYLVIA TOWNSEND WARNER'S EXCERPTS FROM THE PORTRAIT OF A TORTOISE
}

\author{
B. A. Pike
}

The Portrait of a Tortoise is a compilation of extracts from the journals and letters of Gilbert White, made by Sylvia Townsend Warner and with her extended introduction and notes. It was published by Chatto \& Windus in 1946 and originally cost four shillings. It's a small book of sixty-four pages, including the preliminaries, and it has the characteristic elegance of Chatto publications, its green binding lettered gilt on the backstrip. The pale green wrapper is especially choice, with handsome lettering and an engaging drawing of Timothy the tortoise in a garden setting. Whoever designed it did an admirable job. In 1981, Virago published a new edition of the Portrait with only minor changes in layout and design.

The first edition has an unattributed portrait of Gilbert White as frontispiece and page 14 faces a second portrait, of Mrs Rebecca Snooke, White's paternal aunt. Timothy belonged to her until her death, when White took charge of him. Sylvia Townsend Warner's introduction occupies pages seven to twenty-six and her notes a further seven pages later. As endpiece the introduction has a vignette 
of Timothy's carapace. The portrait of Timothy is in two parts, the first assembled from White's journals and the second, much shorter, from The Natural History of Selborne. The notes appear between the two parts and the book concludes with three brief appendices, each occupying a page.

Portrait One, from the journals, begins in 1771 and ends in 1793, the year of White's death. In a brief preliminary note, Warner admits to having allowed herself 'to include some passages which do not directly refer to Timothy' (p.27). She justifies allusions to the weather as providing a context for the tortoise and especially commends the entry for 26 March 1789: 'icicles hang all day. Hot-bed smokes' (p.42). This, she claims, shows White's 'power - like that of some Chinese artist - of conveying a whole landscape with a few strokes' (p.27). She confesses also, to having on occasion 'just given way to personal liking', delighting in 'the astonished bantams' which flew over the house on being confronted with snow, and the 'concatenation in a Naturalist's mind of the fertility of the polyanthus and of the White family' (p.27): '[o]ne polyanth-stalk produced 47 pips or blossoms. Mrs Edmund White brought to bed of a boy, who has encreased the number of my nephews $\&$ nieces, to $56^{\prime}$ (p.43). She ends by implying resistance to temptation to diverge even further: 'Readers who know the journals will be astonished at my moderation' (p.27).

During the 1770s, Timothy lived in the garden of Mrs Snooke at Ringmer and there are entries relating to him for every year except 1774. In March 1780, Mrs Snooke died and two days after her funeral Gilbert White took charge of Timothy. The tortoise was still hibernating and 'when dug out of its hybernaculum, it resented the Insult by hissing' (p.30). Thereafter, the entries are more numerous, as one might expect.

Sylvia Townsend Warner's notes enlarge upon points of interest and draw attention to especially significant entries, such as that for 7 August 1775, which 'contains the first mention of the tortoise by name, his first recorded 
weight and the length of time he had been at Ringmer' (p.47). She also provides supplementary information about him from other sources, quoting from White's letters to his brother Benjamin, his niece Mary and the arboriculturist Robert Marsham.

She places a quotation from Pope (p.49) and provides horticultural information about the Globe thistle and Willowherb (or Echinops and Epilobium angustifolium, to give them their full dignity) (p.48). She refutes White's belief that Timothy is 'the Testudo Graeca of Linnaeus (p.32)', asserting that he was a Testude Ibera; and she is at pains to explain that White's frequent use of the phrase 'Timothy the Tortoise' was not a 'whimsy of nomenclature' but a practical usage imposed by the need to 'distinguish him from Timothy Turner, a farmer of the neighbourhood' (all p.49). The notes encompass also 'the flowers regularly sown by G.W. in his annual bed'; the immunity of bees to loud sounds (p.49); and the unusual height and 'noble appearance' of the Monk's rhubarb, a purgative dock according to Culpeper, but for Gilbert White the wherewithal for a 'well-flavoured' tart (p.52).

Warner delights in the contrast between the 'philosophic' character given to Timothy in a letter of 6 June 1786, addressed to White by a clerical friend, and the diary entry for the previous day, which records his amatory wanderings and departure from his 'usual gravity' (p.41). She also places for us family and friends: White's second brother Benjamin, 'the publisher'; Benjamin's second wife Mary, formerly the widow of his first wife's brother (p.52); the obliging neighbour Benham, who supplies dung, mends hedges and hunts swallows (p.53); the 'weeding-woman' Goody Hampton, who might be taken for a man 'excepting that she wears petticoats and now and then has a child' (p.50); and Dr Chandler, surveyed briefly as preliminary to Appendix 1, which is devoted to him. The penultimate note comments on White's blunt entry for 23 March 1792: 'Crown imperials bud for bloom, \& stink much' (p.45). Warner observes wryly that 'florist's catalogues are not so candid about the Crown Imperial' (p.53). 
Portrait Two consists of extended quotations from five of the letters to the Hon. Daines Barrington that make up the greater part of The Natural History of Selborne. Like its predecessor, it has a brief preliminary passage, this time to reassure readers that the impression it gives of a 'more stately and polished reptile than the Timothy of the Journals' is 'mainly a difference of lighting', arising from the 'moral and philosophical reflections which shade him' (p.54) in the letters to Barrington. The Portrait ends with 'more particulars respecting the old Family Tortoise' (p.60), originally published as a supplement to The Antiquities of Selborne, but now usually included in Letter L of the Natural History of Selborne, despite its inconsistency with the date of that letter.

The first of the appendices improves our knowledge of Dr Chandler, a restless man who likes to be on the move. Warner quotes from a letter from White to Samuel Barker, which includes the arresting information that the doctor particularly favours his small son 'because he is not sure in what kingdom he was begotten'. Dr Chandler is also credited with keeping a 'sharp eye on hirundines'; teaching the White household to "make lime-blossom tea'; and buying a 'pound of English truffles for 2s.6d.' (all p.62). The second appendix quotes a letter from White to his brother John, comparing the structure of Timothy's shell with that of the shells of two smaller tortoises which 'Mrs Snooke had formerly' (p.63); and the last of the three gives a table of Timothy's weight at different times (p.64). He was at his lightest - 6lbs. 4oz. in May 1780 and at his heaviest - 7lbs. 3oz. - in August 1782.

The thirty pages of the Introduction constitute an extended essay by Warner on Gilbert White and his tortoise, very much in her characteristic vein, combining wit with erudition and delighting in the minutiae of life. It opens with the journal entry for 14 August 1790, when 'young Hirundines cluster on the trees' and 'harvest bugs bite the ladies', and continues with Warner's wry comment that this may 'seem a little heartless in its serene objectivity' if 'one is a lady' (p.7). 
She assures us, however, that Gilbert White was not insensitive but a true 'child of his most social century', who 'complied with his ... obligations' as 'friend, host and member of the White family" (p.7) and lived a most genial and hospitable life. It is because he is preeminently a naturalist that he may seem less than sympathetic in this instance. Dominating his life was the 'private love-affair with nature' that 'runs like a chalkstream river, pellucid, tranquil and irresistible' through the 'landscape of Conversation Pieces' (p.7) inhabited by his friends and family. As a naturalist he observes dispassionately, so that the ladies bitten by bugs in August 1790 'take their place in the realm of nature, rolled round in earth's diurnal course' with their attackers and the swallows (p.8).

It is by way of the latter, the ever-present hirundines, that Warner approaches 'the subject of this biography: Timothy, Mrs Snooke's old tortoise' (p.10). Unlike the bugs and the ladies, the swallows have 'the compelling charm ... . of mystery' (p.8). Do they, or do they not, hibernate? White, 'to his life's end ... watched and wondered' (p.8), 'relying on his own observations' (p.10) and hoping to be convinced. An erudite footnote establishes that the $17^{\text {th }}$ century favoured migration as the explanation of the swallows' disappearance in winter, 'laying violent hands on Herodotus' (p.9) in support of its belief. By Gilbert White's day, however, 'the Age of Reason had set in' and 'thought proceeded more cautiously' (p.9) so that supporters of migration were out of date.

At the end of Letter VII to Daines Barrington, White moves on from the consideration of swallows and housemartins to 'a land tortoise, which has been kept for thirty years in a little walled court belonging to the house where I am now visiting' and it is 'thus ... that Timothy first steals into public notice' (p.11). White was staying, of course, with Mrs Snooke, his father's sister. His age was fifty, hers seventy-six, but with Timothy's age we enter 'the realm of supposition'. White 'had been pleased to persuade himself that the tortoise had been born in 
Virginia in 1734 , but all that is certainly known is that Mrs Snooke's husband had bought him for $2 \mathrm{~s}$. 6d (the price of $\mathrm{Dr}$ Chandler's truffles) from a sailor in Chichester 'somewhere around 1740'. With this 'we must content ourselves' (all p.11), as Warner puts it, but she makes it plain that we cannot trust that sailor: apart from the question of his age, Timothy is a 'Mediterranean tortoise' (p.18).

The picture of Mrs Snooke that emerges is 'very much to her credit' (p.12). In particular, she was 'very kind to Timothy' (p.13), feeding him by hand and studying his tastes: 'He ate of her kidney-beans and of her cucumbers' (p.13). The 'little walled court' was 'not the sort of prison-yard the words might suggest': it had a flower border with 'a great tuft of hepaticas' and if Timothy lay unhappily in 'mud and mire' on occasion, it was 'the Ringmer soil' (all p.13) that was to blame and not Mrs Snooke.

After her death, Timothy, 'a valued family friend', 'exchanged the clay-bottomed brick-loam of Ringmer for the black malm of Selborne'. More importantly for his biographer, he came to be "no longer studied as an accessory to swallows' but as himself 'a personality' (all p.15). During that first summer at Selborne, Gilbert White was 'exceedingly attentive' to his tortoise, watching him, weighing him and experimenting on him in various ways. It was established that he could not swim and seemed indifferent to loud noise. Warner detects 'a note of rising triumph' (all p.15) in the journal entries of this time. She assumes that Timothy's 'change of residence' was much to his advantage, 'affording him more scope for curiosity, more room for exercise and a free run among the vegetables' (p.17). When the tortoise behaves oddly, burying himself 'in the laurel hedge', despite having been 'put to bed' in his coop 'in the border under the fruitwall', Warner posits no fewer than four reasons for this, ranging from the lack of a 'quilted sensation' to a preference for sleeping 'austerely' ('like many celebrated characters') (all p.17). She approves of the Selborne garden as 'a very proper sort of garden, growing fruit, 
flowers, and delicate vegetables, very well-loved and highly cultivated'; and she marvels at the tolerance of Gilbert White and Thomas Hoar, his 'friend, gardener and factotum' (all p.18), who allow the tortoise free rein among the Coss lettuces.

The Introduction records changes in Timothy's hibernatory routine and the establishment in various places of his 'hybernaculum', whether the border under the fruit wall, the laurel hedge or 'the hedge against Benham's yard', where a 'thick tuft of grass shelters his back and he will have the warmth of the winter sun' (all p.19). Warner records that the laurel hedge 'suffered considerably' in the 'hard winter of 1784 ', when Thomas Hoar regularly shook the snow off the evergreens; and she imagines him making a routine of this in 'the spell of snowy winters which followed'. Might not Timothy have felt the need to escape the 'vibrations of Thomas's cold stamping feet' and retreated to the Benham's hedge 'for the sake of a little peace and quiet'? (all p.19) A tart footnote expresses the hope that this 'enquiry into Timothy's dormitories' should not seem 'out of proportion', and we are invited to consider that the beds in which Elizabeth I 'spent but a single night' are of abiding interest to historians and that Timothy 'spent from four to five months in his' (all pp.19-20).

One other consequence of that cold winter of 1784 is gleefully recorded by Warner: Gilbert White's parlour-cat was 'so electric that had a person stroked her, and been properly insulated, the shock might have been given to a whole circle of people'. This, she reflects, would doubtless have afforded the cat a 'great deal of quiet satisfaction' (p.19).

Timothy is twice recorded as having wandered more widely, beyond the wicket gate, 'we know not whither' (p.20). In a 'fanciful' (p.21) letter to his niece Mary, White reports his return after an absence of eight days and attributes to a desire to encounter 'beautiful females' (p.20) his having strayed beyond the garden into the meadow. Warner sees this as a 'new aspect' of Timothy, that of 'social being and part of the entertainments of 
Selborne' (p.21). She evidently deplores a letter in verse addressed by Miss Heckey Mulso to Timothy, particularly since it provoked an 'autobiographical letter, or pseudoTimothy', in which White writes in the persona of his pet. For Warner the 'tortoise of the Pseudo-Timothy is a poor Punchinello of an animal, not comparable to the Timothy of the Journals' (all p.21). She laments the 'benign friskings' (p.21) that led White to temper some objective reporting with a jesting reference to a passage from Dryden; and she detects in the jest the 'French accent of $18^{\text {th }}$ century English culture', which nothing 'can smother', not 'all the beef and bullying, not all those deplorable importees from Hanover' (p.22).

As the journals progress through the years, White's 'attention ... must wander' (p.23) and he is forgivably diverted from consideration of Timothy by trees and fernfowls - and 'always the Hirundines, the problem of their behaviour still unsolved' (p.23). Warner sees as 'rather sinister' (p.25) the final entry relating to Timothy, that for 1 June 1793: 'Timothy is very voracious: when he can get no other food he eats grass in the walks' (p.46). In a prolonged drought, Thomas Hoar has fenced off his greenstuffs and Timothy is 'reduced to browsing the grassed walks' (p.25). The flowers are 'still in full beauty' but they are "hardy gypsies compared with vegetables and will flaunt their way through a drought that intimidates cabbages' (p.25).

The Portrait of a Tortoise is a delightful book, in its physical aspect, in its essential preoccupation with Timothy and his courses, and in its incidental insights into Gilbert White and his circle and the mind of Sylvia Townsend Warner. Someone else might have assembled the materials from Gilbert White's writings, but their distinctive presentation is entirely hers.

All quotations are from The Portrait of a Tortoise. Extracted from the Journals and Letters of Gilbert White. Introduction and Notes by Sylvia Townsend Warner. London: Chatto \& Windus, 1946. 